\title{
STRUGGLE FOR NEW MEDIA OF PEACE AND TOLERANCE: A CLOSE LOOK TO THE USAGE OF INTERNET IN DEFINING AND BUILDING YOUNG MUSLIM COMMUNITY IN INDONESIA
}

\author{
Imam Malik Ridwan \\ Surya University
}

\begin{abstract}
As for religion, internet has become a very important aspect in people's everyday live, especially for those who seek information and further understanding about religion; internet is a way in and out to do so. While in one side internet has been a great help in providing sources and opportunity to learn religion in a new way, it also has a negative potential for the growing numbers of radicalism and religious extremism. Various researches and studies have bought up large data showing that these negative effects of internet bring bad influences to religious believers. Nevertheless, the ability of internet in providing and spreading information are also a way out in bringing back religion to its ideal path, that is to evoke peace and welfare among people. Internet is then used as a field for dakwah (proselytizing) to spread more peaceful as well as relevant information on religion and its related topics. Online dakwah is therefore meant to initiate peace and non-violent ways in understanding and practicing religion in real life. Focused targets for the dakwah are youth as the most active users of internet, as well as government to initiate and implement such policies to keep internet clean from violence and extremism.
\end{abstract}

Keyword: Islam, Dakwah, Internet, New Media

The media is a double-edged sword. It can be a frightful weapon of violence when it propagates messages of intolerance or disinformation that manipulate public sentiment, but there is another aspect to the media. It can be an instrument of conflict resolution, when the information it presents is reliable, respects human rights, and represents diverse views. It is a media that reduces conflict and fosters human security (Ross Howard: 2002: 1).

\section{INTRODUCTION}

Indonesia is a country with the largest Muslim population in the world, this country is also one the world's biggest Internet users; 82 million of its populations are internet active users. ${ }^{2}$ Techinasia reported that Indonesia

2 http://kominfo.go.id/index.php/content/detail/3980/Kemkominfo\%3A+Penggu- 
has the second-largest population of Facebook users (35,4 million) and the fourth-largest population of Twitter users with more than 4,8 million of them are actively use it in their daily life, and not to mention the high number of users in other social medias. The big number of social media in Indonesia is in one hand worrying for it is also potentially targetted by radical and extremist movements since many of media users tend to spend their time by going online rather than offline. The latest study of the Berkman Center for internet and society at Harvard University released that 30 million teenagers can have access to internet without parents knowing their activities in it. It somehow danger them since extremists are 'creative' enough to use technology to spread their ideology through videos, tweets and postings released by them. ${ }^{3}$ Today, the internet is a contested terrain, used by Left, Right, and Center of both dominant cultures and subcultures in order to promote their own agendas and interests. ${ }^{4}$

In Indonesian case, Internet has been a key role in creating and sustaining political legitimacy, resistance, and identity formation among Islamic radical fundamentalists. Power and ability owned by internet can even allow users to access global sources of information while interpreting that information in local identity contexts through key nodes and sources. ${ }^{5}$ Thus, it emerges real action to promote and campaign on new internet media encountering and eradicating radicalism, especially among young generation in Indonesia.

Nevertheless, there has been no systematic and massive program carried out by goverment to overcome this challenge. This paper, therefore, is meant to argue that civil society should be empowered by creating new alternative and more creative internet used media to encounter radicalism, especially in muslim community. Based on my research study and experience in developing peace building through internet internet can be well used to uphold a soft campaign on deradicalization and spread the essence of Islamic teachings on peace and tolerance as a basic way of dakwah.

\section{YOUTH AND ISLAM IN INDONESIA}

As a society to consider religion as an important part in life, Indonesian people

na+Internet+di+Indonesia+Capai+82+Juta/0/berita_satker\#.VGwLt9KSxM4 (accessed on 12/04/ 2015).

3 The Jakarta Post, August 07, 2014 (accessed on 10/04/2015)

4 Richard Kahn and Douglas Kellner, "New Media and Internet Activism: From the 'Battle of Seattle' to Blogging" in New Media Society 2004; 6; 87, London: SAGE Publications. p.94

5 To see the research on Islamic Radicalism and Anti-Ameracanism in Indonesia, read further Merlyna Lim, Islamic Radicalism and Anti-Americanism in Indonesia: The Role of the Internet, Policy Studies 18,2005 published by the East-West Center Washington. 
often access Internet to obtain as much as information related to religious issues, either for terms of doctrine, history, or movements/organizations linked -or deliberately linked- to religion. It is certainly a good sign, easy access to internet helps people to get information about religion easily. Although people need to also be aware to negative sides of internet, the nature of the internet -- which is free and not limited by space and time- has made many kinds of information, including those negatives ones, widely spread without reliable filter.

The emergence of too many accounts that spread religious-like information on internet is also vulnerable to the interests that are counter-productive to the enlightenment in Islam. Those unfiltered information has been proved to spread stories that are still in doubt for its validity. Some of those are even impressed to spread slander, hostility towards others, and hatred toward groups outside their own. In fact, if we refer back to the original purpose of the spreading of Islam, or Islamic dakwah movement, negative effects of dakwah as we encounter these days are clearly deviant from its original purpose (to spread peace and prosperity).

Basically, the dissemination of Islam or dakwah is aimed to change the attitude or behavior of people, of the uncivilized become civilized, of the depraved to the good (akhlaq al karima). This refers to one hadith of the Prophet who once said that he was sent to earth to enhance human morality. In essence, the primary purpose of the spreading Islam is in fact to establish good and friendly personality that ean benefit to others.

However, as the time passed, dakwah begins to shift and seem to have other purposes than the formation of individuals to have a certain good or personal piety. In fact, in an effort to spread the teachings of Islam, radical and extremist groups tend to use exclusiveness as the main spirit of it, that is to consider other groups as enemy and thus must be fought. This phenomenon shows that the spirit of the early dakwah of Islam -that is to establish and improve human behavior- has shifted away and fell in a puddle of exclusivism and profane oriented motives, like political or economic motives. One example for it is the case of the refusal of some Islamic organizations to against Ahok or Tjahaya Basuki Purnama from becoming Governor of Jakarta in 2014 merely over his identity of being Christian and Chinese in the same time, where both identities are not in favor for this group.

\section{THE NEED FOR AN EFFECTIVE MEDIUM OF DAKWAH FOR YOUTH}

Most of active Internet users in Indonesia, especially those who use internet 
as a medium to learn about Islam, are youth. Based on the research (that I was invovled in) conducted by the Center for Religious Studies and Nationalism Surya University in the first half of 2014 in 18 cities involving 46 youth respondents (aged 18-24 years), $95.7 \%$ of youth use social media actively, and that $58.7 \%$ of them actively follow online studies on Islam. $78 \%$ of respondents expressed their interest to participate in online dakwah, 59\% of them admitted that dakwah in social media has an impact on the attitude of the youth. This shows that social media can be used as an effective medium for dakwah.

Some respondents stated that dakwah through social media is more readily accepted because there is no element of coercion, compulsion to either to accept the contents of dakwah, or to come to particular locations where dakwah is taking place; they can also perform a variety of reactions to the dakwah they do not agree or enjoy with, starting from simply ignoring, closing the sites, or react by posting certain comments online to it. This suggests that the stigma of coercion on the value, indoctrination, and coercive dogmatism do not occur in the method of Islamic learning through social media.

Furthermore, the awareness of literacy also emerged from some internet active users who became respondents for this research: they stated that dakwah can be done not only through direct verbal methods, but also through writings, like writing in social media. With the role of social media, dakwah can deliver fresher and not coercive information needed, readable at any time, thus no body needs to be felt like they are forced to come to certain places such as teaching in mosques.

Other interesting findings in the research are that respondents indicate the interest of the younger muslim generation to use social media sites and have a better education, by paying more attention to the reference and valid literacy that can be accounted for anytime they learn about Islam online. This suggests that Isłamie learning Islam through social media sites also need to select certain accounts to be used as reference, which is to avoid anonymous accounts that sometimes spread nothing but hatred.

The risk of misuse of accounts by some actors who have counter-productive intentions must also be realized by users of social media, one respondent said that: "The Indonesian younger generation tends to agree to anything said by religious leaders that they trust without questioning and being critical of to it". This indicates that the tendency of Muslim community in Indonesia still has a high dependency on religious leaders. Therefore, religious leaders need to adjust to this condition.

The last question given to respondents was "in your opinion, how to perform 
dakwah that is effective and suited to the younger generation in social media?". Answers were found to be very diverse. All respondents said that the mission should be done in creative ways such as short stories, videos, nice tweets, Images, Comics, Comedies, and online discussion forums. ${ }^{6}$

\section{INITIATING PEACE AND NON-VIOLENCE MEDIUM OF DAKWAH}

Internet and religion are two things that cannot be separated from people's life. Brenda E.B. even claimed that the Internet has evolved into a fertile ground for the development of religion. ${ }^{7}$ It is not excessive, because according to Lorne L. Dawson, internet gives many things for the benefits of religious purposes, ${ }^{8}$ such as:

a. Spreading messages to the whole world. Things that can be spread out through internet facility are religious views and beliefs of an individual. People will then easily access the message for later consideration and may be taken with a mixed reaction.

b. Building a new community. Flagship facility of the Internet is its ability to continue to make its users communicate over long distances, either personally or in group form. Religious communities and anyone who are studying religion can create or join to a cyber-community that focuses on religious issues.

c. Fusing the limits of space and time. Internet users, especially religious experts, gain a great help from internet in disseminating their studies and views on religious teachings throughout the world, regardless of limits in space and time. Thus their views can easily be accessible to many more people.

d. Performing religious rituals in cyberspace. With the development of technology, the Internet provides a facility that allows many people to do a variety of rituals in the virtual world, but of course it is in a total different meaning.

e. Develop a more open understanding in religion. The abundance of information about religion and its teaching available on the internet allows in-

6 Imam Malik and Yuni Chairani, 2014a, Laporan Hasil Penelitian Penggunaan Social Media sebagai Media Pembelajaran Islam, Jakarta: Center for Religious Studies and Nationalism Surya University, p.12-16.

7 Brenad E. Brasher. 2001. Give me that ONLINE RELIGION. San Francisco: JosseyBass. P.11

8 Lorne L. Dawson. 2004. "Doing Religion in Cyberspace: The Promise and the Perils". In The Council of Societies for the Study of Religion Bulletin. 30, No. 1, pp. 3-9. See also: Syarif Hidayatulah dan Zulfikar S. Dharmawan, 2004. Islam Virtual: Keberadaan Dunia Islam di Internet. Ciputat: Penerbit MIFTA. 
ternet users to get more and more insight that can be used as reference material for self-reflection, comparison, and strengthening of faith, so that understanding on religion can be more open.

However, vigilance toward new media is also worth maintaining, as Mara Einstein states that Internet is also a fertile ground for religious businessmen. ${ }^{9}$ This is one thing that encourages many people to post or download information related to religion, the internet provides almost limitless freedom for anyone to do anything. Internet can change a taxi driver to become propagators without undergoing any selection for it. 'Virtual religious' leader can easily gather the congregation with no bother of going in and out of certain community area to preach.

Here is where the problem starts; when everyone can easily be cleric, who then is the students? Dawson and Cowan predict that particular problem that is likely to arise from this phenomenon is the crisis of authority and authenticity on religion itself. ${ }^{10}$ Truth meaning of religious teachings are no longer owned by those who have a broad knowledge of religious and social piety good, as the criteria of a religious leader who must have a noble character and extensive knowledge in all disciplines of religion. ${ }^{11}$ Internet has therefore no filter for thoughts and writing to pop-up, this can dangerously confuses the minds of the internet users to distinguish what is true and what is not.

However, regardless of anxiety and vigilance over it, the internet remains a very effective medium to perform dakwah. Respondents in this study seemingly do not feel too bothered about "who said what", they will tend to follow the contents of dakwah on the internet as long as they:

- do not patronize

- are not too rigid and raw

- use light language

- are linked with youth daily lives and issues that are happening

- consider the psychology of the younger generation

9 Mara Einstein. 2008. Brands of Faith: Marketing Religion in a Commercial Age. New York: Routledge.

10 Lorne L. Dawson and Douglas E. Cowan, ed. 2004. Religion Online: Finding Faith on the Internet. New York: Routledge.

11 There are many categories given by the scholars and Muslim thinkers regarding to the conditions and criteria for someone to be a preacher. Some of which can be viewed at: Muhammad Rajab al-Shatiwi. 1990. al-Da'wah al-Islamiyya al-Kitab fi Daw'i wa al-Sunnah, Cairo: Dar al-Tiba'ah al-Muhammadiyyah. Muhammad Amhazun. 2003. Manhaj al-Nabi min Khilal fi Da'wah al-Sirah al-Sahihah. Cairo: Dar al-Ssalam., 'Abdullah Nasih' Ulwan, 2004. Lineage Madrasah al-Du'at. Cairo: Dar al-Ssalam. 'Abd al-Karim Zaydan, 2001. Usul alDa'wah. Beirut: Mu'assah al-Risala. 
- concern the most to aspects of tolerance that does not offend other religions

- contains motivation and call on the virtues

Therefore, dakwah via Internet should be done in a sustainable manner and with above consideration, that is to pack dakwah with creative works, such as video, images, animations and any other forms, and contain teachings that concern to aspects of tolerance and non-violent acts, use light and understandable language, and contains of motivation and call on virtues. ${ }^{12}$

One of the current new media that promote peace and non-violent dakwah in Indonesia is a website named www.Jalandamai.org. It is a website and social media network accounts to campaign peace, tolerance, and anti-violence acts. In its young age, jalandamia.org has become a kind of brand to overshadow campaigns on peace and anti-violence initiated by the Center for Religious and Nationalism Studies and DIgicom of Surya University in cooperation with BNPT (National Counter-Terrorism Agency).

After studying the relationship of students/youth inclination in new media as well as the way they learn and gather information, jalandamai.org decided to provide a variety of service models. In addition to providing short-grain writings that are reflective and focus on exploration of differences, jalandamai. org also provides video monologue full of meaning packed in speed drawing form. Jalandamai.org also provides services on Islamic learning and technology through Edmodo app linked in jalandamai.org page.

The ultimate goal of jalandamai.org is to form reliable understandings of readers to become persons that accept differences and always provide benefits to others and continue to express the attitude of peace and non-violence. To show a firm stance on the vision of peace and non-violence is an important action because silent on violence is the unspeakable support for it. ${ }^{13}$

\section{CONCLUDING REMARK}

The Internet and its linkages to other media have enabled the realization of new networking. Radical groups use the Internet as a trawling tool to reach potential members at local, national, and global levels. Indonesia, as one of the

12 Imam Malik and Yuni Chairani, 2014b, Laporan Hasil Penelitian Persepsi Generasi Muda terhadap Video Kampanye Islam Damai sebagai Bentuk Dakwah Kreatif, Jakarta: Center for Religious Studies and Nationalism Surya University, p.11-12.

13 To know more in detail, see further the website of jalandamai.com and see also the report on peace and non-violence media perceived by young generation in Indonesia, Imam Malik and Yuni Chairani, 2014c, Persepsi Generasi Muda Muslim Mengenai Toleransi terhadap Keberagaman Agama di Indonesia, Jakarta: Center for Religious Studies and Nationalism Surya University. 
largest social media users, has been a target of dessimination for radicalism and the transnational radical movements, especially for young generation.

To overcome this challenge, government has to optimalize its programs on deradicalization, specifically through internet media. One of the effective ways is to promote and campaign peace and non-violence acts through internet by involving young people since they are "the real players" of today's media. This will influence and empower civil society since "the real public sphere and the power of civil society" today is in virtual sphere-the internet- with all elements on it. ${ }^{14}$ Therefore, young generation have has to take account as the main subject to strenghten the power of civil society such as what has been developing by muslim youth through jalandamai.com.

\section{REFERENCES}

al-Shatiwi, Muhammad Rajab. 1990. al-Da'wah al-Islamiyya al-Kitab fi Daw'i wa al-Sunnah, Cairo: Dar al-Tiba'ah al-Muhammadiyyah.

Amhazun, Muhammad. 2003. Manhaj al-Nabi min Khilal fi Da'wah al-Sirah al-Sahihah. Cairo: Dar al-Ssalam.,

Abdullah Nasih' Ulwan, 2004. Lineage Madrasah al-Du'at. Cairo: Dar alSsalam.

Brasher. Brenad E. 2001. Give me that ONLINE RELIGION. San Francisco: Jossey-Bass.

Dawson, Lorne L. and Douglas E. Cowan, ed. 2004. Religion Online: Finding Faith on the Internet. New York: Routledge.

. "Doing Religion in Cyberspace: The Promise and the Perils". In The Council of Societies for the Study of Religion Bulletin. 30, No. 1

Einstein, Mara. 2008. Brands of Faith: Marketing Religion in a Commercial Age. New York: Routledge.

Hidayatulah, Syarif and Zulfikar S. Dharmawan, 2004. Islam Virtual: Keberadaan Dunia Islam di Internet. Ciputat: Penerbit MIFTA.

Kahn, Richard and Douglas Kellner, "New Media and Internet Activism: From the 'Battle of Seattle' to Blogging" in New Media Society 2004; 6; 87, London: SAGE Publications.

Malik, Imam and Yuni Chairani, 2014a, Laporan Hasil Penelitian Penggunaan Social Media sebagai Media Pembelajaran Islam, Jakarta: Center for Religious Studies and Nationalism Surya University (tidak diterbitkan).

14 Merlyn Lim, "Informational Terrains of Identity and Political Power: The Internet in Indonesia” in ANTROPOLOGI INDONESIA 73, 2004. p.10. 
2014b, Laporan Hasil Penelitian Persepsi Generasi Muda terhadap Video Kampanye Islam Damai sebagai Bentuk Dakwah Kreatif, Jakarta: Center for Religious Studies and Nationalism Surya University (tidak diterbitkan).

2014c, Persepsi Generasi Muda Muslim Mengenai Toleransi terhadap Keberagaman Agama di Indonesia, Jakarta: Center for Religious Studies and Nationalism Surya University (tidak diterbitkan).

Lim, Merlyn. "Informational Terrains of Identity and Political Power: The Internet in Indonesia" in ANTROPOLOGI INDONESIA 73, 2004.

Lim, Merlyna. Islamic Radicalism and Anti-Americanism in Indonesia: The Role of the Internet, Policy Studies 18,2005 published by the East-West Center Washington.

Zaydan, Abd al-Karim, 2001. Usul al-Da'wah. Beirut: Mu’assah al-Risala.

The Jakarta Post, August 07, 2014 (accessed on 10/04/2015)

http://kominfo.go.id/index.php/content/detail/3980/Kemkominfo $\% 3 \mathrm{~A}+$ Pengguna+Internet+di+Indonesia+Capai+82+Juta/0/berita_satker\#.VGwLt9KSxM4 (accessed on 12/04/ 2015). 